\title{
Between development and sustainability: symbiotic synergy or irreconcilable duality
}

\author{
Agata FERREIRA \\ ESADE, Ramon Llull University, Barcelona, Spain
}

\begin{abstract}
:
Aim: This paper studies the concept of sustainable development, which has been overly present in recent times on global arena of debates about issues most pressing to humanity in variety of contexts, political, legal, social and environmental. It has been appropriated by governments and NGOs alike. It is being advocated to promote both, continuous growth and reversal of unsustainable pattern of limitless growth. The aim of this paper is to follow the history of the concepts of development and sustainability, its evolution and current status and question whether future developments in the area of sustainable development are likely to support "development" part of it, through drive to maximum economic growth, increase of financial flows and investments, consumption and production; or whether the "sustainability" part of the agenda, with protection of environment, human rights and climate as a priority, will prevail.
\end{abstract}

Design / Research methods: The article follows the historical origins and developments of the concepts of development and sustainability, since industrial revolution of the eighteenth century where progress has been linked with economic growth and material advancement. The concept of sustainability on the other hand is closely connected with human relationship with nature, which went through a profound change when people started to make permanent settlements, domesticate animals and farm the land. This paper explains how sustainable development term rose to political prominence following publication of the Brundtland report in 1987 and how subsequent global political initiatives, like Agenda 21, Johannesburg Declaration and 2030 Agenda, gradually reaffirmed the place of sustainable development as an important element of international agenda and broadened the meaning of the term.

Conclusions / findings: The role of business partner is present in $10 \%$ of the examined enterprises, with the source of capital and the entity size being of minor importance. Projects play a key role in the development of contemporary undertakings. Moreover, the primary role in terms of the implementation of any organizational activities is exercised by people. Thus, the opportunity emerges to implement and modify the concept of HR business partnering. This will lead to a greater professionalization of staffing, which will ultimately affect positively the implementation of strategy of the organizations under discussion.

E-mail: agata.ferreira@alumni.esade.edu

Received: 18-05-2017, Revised: 14-06-2017, Accepted: 16-06-2017 
Originality / value of the article: The publications on project management as well as those concerned with human resources management have so far not addressed the issue of the development of the HR business partner role in the organizations under discussion. The considerations, of both theoretical and practical nature, contribute to the theory of management, being much relevant owing to the ever growing popularity of the concept of management through projects.

Implications of the research: project management, project-oriented organization, HR department, HR business partner

Key words: project management, project-oriented organization, HR department, HR business partner

JEL: M12

\section{Introduction}

Sustainable development concept has been widely used and is often evoked, in variety of contexts political, legal, social and environmental. The phrase "sustainable development" has been overworked and it seems to suit all, regardless of the agenda. It has been appropriated by governments and NGOs alike. It is being advocated to promote both continuous growth and reversal of unsustainable pattern of limitless growth. It potentially has so many meanings that it risks being meaningless. The phrase is so ambiguous that it is not far from defying logic. It is an oxymoron in itself. "Development" stands for increase, expansion, extension and always seeking more. In a world of finite resources, such infinite augmentation is not sustainable. The two words together "development" and "sustainable" are contradictory. This article aims to analyse the historical origins and evolution of the concept and its place in the modern globalized world to understand whether any future developments in the area of sustainable development are likely to support "development" part of it, through drive to maximum economic growth, increase of financial flows and investments, consumption and production; or whether the "sustainability" part of the agenda, with protection of environment, human rights and climate as a priority, is likely to prevail. 


\section{Early developments before Brundtland Report}

A good starting point would be to understand how development, or progress, has been understood throughout human history. Studying the human understanding and vision of the idea of progress will help to understand whether it needs to be sustainable. It was the Hebrew and Christian theology, giving expression to the linear conception of time as a directed succession of events, that transformed the way of thinking about history and progress (Du Pisani 2006: 84). The linear and continuous path of progress was supposed to lead to continuous improvements of human condition, first understood in spiritual sense and later on also in material dimension. During the period of Western modernity, linear dimension of progress was linked with science as a way to achieve human potential. Only during industrial revolution, from the eighteenth century, progress was also linked with economic growth and material advancement. In pursuit of maximization of economic production, people saw it right to dominate and exploit the nature. Nineteenth century brought optimism and belief in scientific and technological advancement that would lead to continuous progress of human kind and improvement of human life. The idea of progress, which had its final breakthrough during the Enlightenment, can rightly be regarded as a secularized heir to the Christian ideal of salvation story (Von Wright 1997: 5). However, industrial capitalism, growing gap between poor and rich and unprecedented scale of exploitation of raw materials, led to increasing concerns about the sustainability of this particular idea of progress.

That leads to the second aspect of the term "sustainable development" - concept of sustainability. Human relationship with nature went through a profound change when people started to make permanent settlements, domesticate animals and farm the land. The nature started to be exploited, shaped, utilized and subordinated by man, albeit firstly on a small scale of first settlements. Ownership of land and notions of material wealth as a source of power transformed human thought and allowed unprecedented success of human race. As early as in the ancient Egyptian, Mesopotamian, Greek and Roman civilizations environmental problems such as deforestation, salinization and loss of fertility of soil occurred, which we would today refer to as sustainability problems. Plato in the 5th century BC, Strabo and 
Columella in the 1st century BC and Pliny the Elder in the 1st century AD discussed different types of environmental degradation resulting from human activities such as farming, logging and mining (Du Pisani 2006: 85). Industrial revolution brought concerns of degradation of nature into a sharp focus, mainly in wood industry, as the wood was the primary source of energy and main raw material. Overpopulation was another raising concern noted in the eighteenth century by Thomas Malthus in the most influential book on population of his era, "Essay on the principle of population as it affects the future improvement of society". His theory suggested that, as the population grows, it leads to a rising supply of labour and, consequently, results in lower wages. Malthus claimed that continually growing population would eventually end in poverty. He is considered the first economist that foresaw limits to growth due to absolute scarcity of resources. The Malthusian theory of "environmental limits" may be considered a precursor to the concept of sustainable development (Mebratu 1998: 499). As the energy production shifted from wood to coal in the nineteenth century, new concerns have arisen, regarding preserving of coal reserves. Among the works which contributed to the later development of the concept named sustainable development were "Principles of political economy" of 1848 by John Mill, which advocated "stationary state" of world's population, "Man and nature" of 1864 by George Marsh advocating conservation efforts and "Our wonderful century" of 1898 by Alfred Russell Wallace, which included chapter on the plunder of the earth and which themes were later covered in the Brundtland Report of 1987.

Twentieth century, with its industrial and commercial expansion, destructive global wars and extraordinary technological advances, brought the ideas of growth, development and sustainability into attention again. The propositions of a "stationary state" were rejected in favour of progressive economy and faith in advances in technology providing solutions to the problems of limited resources (Hicks 1941: 32). Against the backdrop of the widening gap between rich and poor countries and colonisation, a theory about development focused around two approaches, modernization and dependency theory. Modernization theory was based on liberal values and encouraged free market economy model, which would lead to continuing economic growth and eventually even out wealth distribution. 


\section{BETWEEN DEVELOPMENT AND SUSTAINABILITY ...}

Modernization was the early sociocultural equivalent of neoliberalism. According to this theory, development meant assuming the mental models of the West (rationalization), the institutions of the West (the market), the goals of the West (high mass consumption), and the culture of the West (worship of the commodity) (Peet, Hartwick 2009: 132). This line of theory is an important element that links the idea of what is considered a development with the Western neoliberalism and globalization. Dependency theory of development on the other hand proposed the solution opposite to the modernization theory. As the Third World countries become more and more dependent on Western countries, leading to further underdevelopment and bankruptcy (So 1990: 108), developing countries should sever their linkages with Western capitalist countries in order to follow an autonomous, independent path of development based on socialism (So 1990: 262). These two theories evolved and adapted, but their basic principles remained influential in the evolution of sustainable development and are still present nowadays.

From around late 1960s new realization came to light, that of an impossibility of continuous linear progressive development. The collateral damage of such development was being evident in technologies being used in destructive ways, colonial exploitation, pollution, unchecked population growth, resource depletion and ravaging of nature. Two aspects of the theory of continuous growth were being questioned. Firstly, environmental damage due to extraordinary industrial and commercial expansion led to few major works on the subject (Carson 1962; Ehrlich 1968; Goldsmith 1972, or Schumacher 1973) and creation of first green movements (Friends of Earth and Greenpeace being the main ones). Secondly, worldwide crisis of the 1970s brought about the realisation of the limits to growth and questioned the possibility of continuous unlimited economic growth. As a result of the growing awareness of these issues, in 1968 the Club of Rome was founded, consisting of current and former heads of states, UN bureaucrats, high-level politicians and government officials, diplomats, scientists, economists and business leaders. In 1972 the Club of Rome released a report "The Limits to Growth", which has sold 30 million copies in more than 30 translations, making it the best-selling environmental book in world history. The publication received considerable public 
attention and is regarded as the key moment in the transformation of disparate anxiety about environmental problems into more focused discussion of an alternative to present-day society (Kenny 1994: 229). The book warned of a sudden and uncontrollable decline in human population and capacity and inevitable catastrophe, if the exploitation of earth resources continues to grow at the same pace. The raising voices questioning whether the continuing growth is desirable or possible were met with the advocates of growth, who believed in human potential to develop solutions and counter the damage. The remedy to these evils is then seen in furthering scientific research and technological development, in the evolutions of various "anti-technologies" to counteract the damage caused by industrialization and wasteful consumerism (Von Wright 1997: 12).

From these two counter positions, one opposing unlimited continuous growth and the other warning of an imminent disaster resulting from exceeding limits of exploitation of earth resources, came a compromise proposition of a growth that is sustainable. At the start of the 1970s the term "sustainable development" was coined, probably by Barbara Ward (Lady Jackson), founder of the International Institute for Environment and Development (Du Pisani 2006: 91). It was becoming clear that the pattern of growth cannot simply follow the Western formula of high consumption, as this would be simply unsustainable for the planet. The growth had to change trajectory to include realisation of finite non-renewable resources of the earth. The focus would need to shift from the quantity of growth as a measurement of progress to the quality of it. In his book "Small is Beautiful" Schumacher introduced a concept of appropriate technology that takes into account population levels, skills, natural resources available and most important social needs. Some experts believe that the concept of appropriate technology is the immediate precursor to the concept of sustainable development (Mebratu 1998: 500).

\section{Brundtland Report and its legacy}

The following years brought more focus on the environment, eco-friendly development and conservation. However, sustainable development term rose to 
political prominence following the publication in 1987 of the UN-sponsored World Commission on Environment and Development report "Our Common Future" (WCED 1987), also known as Brundtland report (named after its chair, Gro Harlem Brundtland, then prime minister of Norway and later head of the World Health Organization). It contained key statement that "humanity has the ability to make development sustainable to ensure that it meets the needs of the present without compromising the ability of future generations to meet their own needs" (Brundtland Report 1987: par. 27). This is still the benchmark definition for the term. It was recognized that the concept of sustainable development "does imply limits - not absolute limits but limitations imposed by the present state of technology and social organization on environmental resources and by the ability of the biosphere to absorb the effects of human activities" (Brundtland Report 1987: par. 27). The report highlighted three fundamental components of sustainable development, known as the triple bottom line, environment, economy, and society. The United Nations Conference on the Human Environment, known as the Stockholm Conference had introduced environmental concerns to the political development discussion. On the other hand, it also introduced political dimension to previously environmental concept. The definition proposed by the Brundtland Report is sufficiently vague and wide, that it allows for variety of interpretations as well as misuse of the term. There is some truth in the criticism that it has come to mean whatever suits the particular advocacy of the individual concerned (Pearce et al. 1989: 1). Brundtland Report was a significant moment in the evolution of sustainable development idea. Sustainable development entered onto a political arena, as it fits nicely into political sound-bites compared with its predecessor's "eco-development", it sounds like something we should all approve of, like "motherhood and apple pie" (Mebratu 1998: 502). The Brundtland Report's discussion of "sustainability" is both optimistic and vague. The Commission probably felt that the discussion had to be optimistic, but given the facts, it was necessary to be vague and contradictory in order not to appear to be pessimistic (Bartlett 2006). The formula proposed in the report was a vague slogan behind which first world politicians with green electorates to appease, and third world politicians with economic deprivation, could unite (Brenton 1994). 
Brundtland Report marks the beginning of an extraordinary political career of the concept of sustainable development. The political dimension of sustainable development concept reached global ambit at the United Nations Conference on Environment and Development (UNCED or Earth Summit) in Rio de Janeiro in 1992, on the twentieth anniversary of the Stockholm Conference on the Human Environment. The significance of the summit was in the fact that it was the largest environmental conference ever held. More than 100 heads of state and representatives from 178 nations, NGOs agencies and other interested parties (approximately 30,000 in total) attended the conference. The objective was to build upon the Brundtland Report legacy and respond to the global environmental challenges and to reach global agreement on measures reconciling economic development with sustainability. The major outcomes of the conference were several documents: the Convention on Biological Diversity, the Framework Convention on Climate Change, Principles of Forest Management, the Rio Declaration on Environment and Development (the "Rio Declaration") and the Agenda 21, which together cover all aspects of sustainable development. The Rio Declaration was in fact a short document, containing twenty seven principles of humanity and sustainable development. It contained several important statements. "Human beings are at the center of concerns for sustainable development. They are entitled to a healthy and productive life in harmony with nature" (Rio Declaration 1992: Principle 1). "The right to development must be fulfilled so as to equitably meet developmental and environmental needs of present and future generations" (Rio Declaration: Principle 3). "In order to achieve sustainable development, environmental protection shall constitute an integral part of the development process and cannot be considered in isolation from it" (Rio Declaration 1992: Principle 4). The Agenda 21 complemented the Rio Declaration with 800-page blueprint for sustainable development. It emphasised economic and social development and environmental protection as basic foundations of sustainable development. The main goal of the Agenda 21 was to ensure that development proceeds in a sustainable way through the system of incentives and penalties to motivate economic behaviour. Other goals were elimination of poverty and sustainable use of global and regional resources such as atmosphere, oceans, seas 
and fresh water, and marine life. In the end however, despite the environmental focus, the biggest arguments at the summit came down to a matter of money, consumptions rates and population growth. The developed countries were calling for sustainability and environmental protection. The developing countries demanded resources to meet the environmental tasks and advocated for their own right to development in order to level out with the developed world. The tensions between North and South and the financial conflicts underlined every major negotiation. Maurice Strong, the Secretary General of the UN Conference said in its closing statement: "It is not a final and complete action programme, and was not intended to be, but one which must continue to evolve. And, I have to say, we still don't have all the means, by any measure, to carry it through. On finance, we have agreement, but not yet sufficient commitment. We have made a start on finance but we must recognize that we are a long way from meeting the needs for full implementation of Agenda 21". Sustainable development was now firmly on the political agenda and as a principle visible globally. However, apart from that, there was a dichotomy, differences in interests between developing and developed world and lack of financial or legally binding commitment. "Strong, secretary-general of the event, was torn. Was he bound by a promise to admit to failure if that was the outcome? Or was completion of the negotiations - the largest assembly of world leaders in history - in itself a success to be acclaimed?" (Pearce 1992: 4). The road to alignment between economic progress and sustainable development proved to be a difficult one.

A parallel agenda had been ongoing within the United Nation forum, which found its expression in the adoption of the Millennium Development Goals ("MDGs") established following the adoption of the United Nations Millennium Declaration during Millennium Summit of the United Nations in 2000. Among the main goals of the MDGs, like eradication of extreme poverty and hunger, achievement of universal primary education, promotion of gender equality, improvement of maternal health and reduction in child mortality as well as combating HIV/AIDS, malaria, and other diseases were also environmental sustainability and global partnership for development. The main theme of the MDGs was reduction of various dimensions of poverty in the developing countries, with the 
focus being directed on human wellbeing, rather than long term sustainability in global terms. Therefore, even though they aimed to address global challenges to development, MSGs did not emphasise sustainable development as its underlying concern.

Ten years after Rio Earth Summit, the Johannesburg Declaration on Sustainable Development (the "Johannesburg Declaration") was adopted at the World Summit on Sustainable Development in Johannesburg, also known as Rio +10 Earth Summit. The understanding of sustainable development concepts was broadened and its place as an important element of international agenda was reaffirmed. The Johannesburg Declaration reconfirmed commitment of nations to sustainable development and recognised the interdependent and mutually reinforcing pillars of sustainable development - economic development, social development and environmental protection - at the local, national, regional and global levels (Johannesburg Declaration 2002: par: 1 and 5). Interestingly, it also acknowledged link between globalization and sustainable development: "Globalization has added a new dimension to these challenges. The rapid integration of markets, mobility of capital and significant increases in investment flows around the world have opened new challenges and opportunities for the pursuit of sustainable development. But the benefits and costs of globalization are unevenly distributed, with developing countries facing special difficulties in meeting this challenge" (Johannesburg Declaration 2002: par. 14). The Johannesburg Declaration was followed by an Annex containing the Johannesburg Plan of Implementation, a 65-page document stating targets and commitments in various targeted areas. Overall however, the Johannesburg summit did not achieve much apart from general goal setting declarations and political statements and no practical steps or commitments to carry out those declarations or fulfil promises. While much of the Plan's language may be grammatically unsatisfactory, there is nothing in it that is accidental. When the carefully drafted pronouncement of a major international meeting is left fuzzy, the reason usually is unresolved differences over policy (Anderson, Morgenstern 2003). The Unites Nations process generated great criticism for its gap between pledges and promises and actual performance. 
The follow up initiative took place in Rio in 2012 (Known as Rio + 20 Earth Summit), organized by the United Nations Department of Economic and Social Affairs. The conference was to ensure that the Agenda 21 and commitments from previous earth summits were being reaffirmed. It also linked Millennium Development Goals with the sustainable development efforts. Paragraph 246 of the outcome general assembly resolution called "The Future We Want" states: "We recognize that the development of goals could also be useful for pursuing focused and coherent action on sustainable development. We further recognize the importance and utility of a set of sustainable development goals, based on Agenda 21and the Johannesburg Plan of Implementation [...] The development of these goals should not divert focus or effort from the achievement of the Millennium Development Goals" (The Future We Want 2012: par. 246) It is worth noting that, even though the conference was held to be the biggest even ever organized by the United Nations, several key global leaders, like Barack Obama, Angela Merkel or David Cameron, representing G20 countries, did not attend.

\section{2030 Agenda for Sustainable Development and Beyond}

Finally, the latest development on a global scale was a resolution adopted on 25 September 2015 by all 193 countries of the United Nations General Assembly called "Transforming our world: the 2030 Agenda for Sustainable Development" ("SDGs Resolution"). The resolution outlines 17 sustainable development goals ("SDGs") and its associated 169 targets. It is considered a successor to the MDGs, which expired at the end of 2015, but also builds on the principles of the resolution The Future We Want. As such, the sustainable development goals have been merged with the development targets into one common, global initiative (SDG Resolution 2015: par 249). The opinions about the SGDs range from unfettered support (KiMoon 2015) to hard critique (Hickel 2015). The new goals are more ambitious than their predecessors. They seek to eliminate rather than reduce poverty, and include challenging targets on health, education and gender equality. They are also universally applicable to all countries and all people, unlike the MDGs, which were 
focused on improving the situation in poor countries. They also include new issues that were not in the MDGs such as climate change, sustainable consumption, innovation and the importance of peace and justice for all. What is also significant about the new goals is the success of the process of getting 193 member nations to agree on them in the first place. "Sustainable development" term appears about 110 times in the SDGs Resolution. Goal 17 is entirely dedicated to strengthening, implementation and revitalization of the global partnership for sustainable development. Without the doubt, sustainable development has become a flagship for largest global political initiatives. And this is where the ambiguity and contradiction of the term, of its meaning and understanding, becomes evident. Even the SDGs Resolution itself recognises that there are different approaches, visions, models and tools available to each country, in accordance with its national circumstances and priorities, to achieve sustainable development. It is truly impossible to extract a single definition of sustainable development from a 35-page document of the SDGs Resolution. It appears as everything from the "consumption and production", "economic growth", "human habitats", "energy", "agriculture", "industrialisation", "transport systems", "management of natural resources", "tourism", "lifestyles", "public procurement practices", "forest management", "livelihood opportunities" and "debt levels" should be sustainable. Even fish stock should produce maximum yield that is "sustainable". Just about everything needs to be sustainable. Generally, it is needed to shift the world on to a sustainable and resilient path (SGDs Resolution 2015: Preamble). However, this path seems to rely on the existing model of pursuit economic growth and the actions proposed are in support of "sustainability" of such growth. This is the mortal flaw at the heart of the SDGs. How can they be calling for both less and more at the same time? (Hickel 2015). Goal 8.1 calls to sustain per capita economic growth in accordance with national circumstances and, in particular, at least 7 per cent gross domestic product growth per annum in the least developed countries. The SDGs reinforce current pattern of human development albeit acknowledging that planet Earth and its ecosystems are our common home and that all human beings can enjoy prosperous and fulfilling lives and that economic, social and technological progress occurs in harmony with nature (SDGs Resolution 2015: Preamble). The conclusion could be potentially 


\section{BETWEEN DEVELOPMENT AND SUSTAINABILITY ...}

confusing. As mentioned in the opening remarks of this article, the "development" stands for increase and always seeking more but such infinite expansion is not sustainable given the limited resources of the planet. "Development" and "sustainable" contradict each other. SDGs call for protection of water ecosystems, biodiversity, fish stocks, forests, climate on one hand and set ambitious growth targets on the other hand. Therefore, what appears to have to be sustained is production, consumption and economic growth. Proliferation of SDG targets is not an indication of reservoirs of opportunity, but rather a form of desperation as to how the economic in its current formulation can be maintained (Moore 2015).

Year 2015 was rounded up with the latest initiative in the field of sustainable development, United Nations Climate Change Conference, as part of the annual session of the United Nations Framework Convention on Climate Change and the annual meeting of the parties to the Kyoto Protocol. The most important outcome of the conference is a global agreement on the reduction of climate change negotiated and agreed by the 196 parties attending the conference. The parties agreed to make efforts to limit the temperature increase of the planet to $1.5 \mathrm{C}$ and achieve zero net anthropogenic greenhouse gas emissions in the second half of the 21 st century. Sustainable development principles are strongly emphasised in the Paris agreement. The signatories recognise social, economic and environmental value of voluntary mitigation actions and their co-benefits for adaptation, health and sustainable development. The role of sustainable development in reducing the risk of loss or damage associated with the adverse effects of climate change has also been recognised. However, the agreement also stresses the critical importance of innovation as an effective, long-term global response to climate change and promotion of two parallel goals, economic growth and sustainable development. The agreement is to be implemented to reflect equity and the principle of common but differentiated responsibilities, recognising different national capabilities and circumstances.

During 2015, being a golden year for sustainable development global initiatives, leaders of G20 emphasised growth as their main focus in the announcement following their latest summit in Turkey. They reaffirmed their commitment to lift collective G20 GDP by an additional 2 percent by 2018 . They 
also resolved to remain resolute to continue collective action to lift actual and potential growth of economies, support job creation, strengthen resilience, promote development and enhance inclusiveness of policies. On sustainable development itself, G20 leaders merely acknowledged that the year 2015 was crucial and reaffirmed their commitment to ensuring inclusive and sustainable growth.

\section{Conclusion}

Sustainable development message appears to be projected globally loud and clear, but, as illustrated in this paper, on a closer inspection the scope and meaning of sustainable development becomes ambiguous. Despite or perhaps because of being discussed considerably and frequently and introduced into main global political initiatives, sustainable development is an indefinite concept, wide open for interpretation, agreeably resonating and curiously uncontroversial. Sustainable development is the product of many stories, worldviews, values, actions and perspectives, it is a collage or kaleidoscope of shapes, colour and patterns, that change constantly (Blewitt 2008: ix-x).

The aim of this paper was to study the concept of sustainable development, to understand whether it is more linked with the "development" part of it meaning maximizing economic growth, capital flows, investments and consumption; or whether the "sustainability" part of the concept and protection of environment, human rights and climate is a dominant theme. On the basis of the analysis presented in this paper, it is impossible to avoid the conclusion that, given current political and economic global background, the main context of sustainable development remains focusing on sustaining economic growth. Economic growth remains the main global objective and growing awareness of the ecological threats to the planet serves as a background in which such continuing economic growth needs to the sustained. We are on an unsustainable trajectory, and we do not seem to know how to get off. Since the $17^{\text {th }}$ century, our economic models and social and political institutions have promoted a version of human flourishing and prosperity synonymous or concurrent with the growth of material wealth (Moore 2015). 
From the Malthusian theory of the environmental limits and from calls for change from quantity to quality as a measure of progress in "Small is Beautiful" by Schumacher, sustainable development has made an extraordinary political career, has grown into prominence, has outgrown itself and ultimately has been watered down by being attached to just about everything.

\section{Bibliography}

Agenda 21: Programme of Action for Sustainable Development, U.N. GAOR, 46th Sess., Agenda Item 21, UN Doc A/Conf.151/26.

Anderson J.W., Morgenstern R. (2003), The future of sustainable development. The Johannesburg Conference and what happens next, ,Resources for the Future”, Issue Brief 03-06, July.

Bartlett A. (2006), Reflections on sustainability, population growth, and the environment, in: The future of sustainability, ed. Keiner M., Springer, Dordrecht.

Brenton T. (1994), The Greening of Machiavelli. The evolutions of international environmental politics, Royal Institute of International Affairs, London.

Blewitt J. (2008), Understanding sustainable development, Earthscan, London.

Carson R. (1962), The silent spring, Houghton Mifflin, Boston.

Du Pisani J. (2006), Sustainable development - historical roots of the concept, „Environmental Sciences", vol. 3 no. 2, pp. 83-96.

Ehrlich P. (1968), Population bomb, Buccaneer Books, New York.

Goldsmith E. (1972), Blueprint for survival, Houghton Mifflin, Michigan.

Hickel J. (2015), The problem with saving the world. The UN's new Sustainable Development Goals aim to save the world without transforming it, "Jacobin", https://www.jacobinmag.com/2015/08/global-poverty-climate-change-sdgs/ [25.06.2017].

Hicks J. (1941), Value and capital. An inquiry into some fundamental principles of economic theory, Clarendon Press, Oxford.

Johannesburg Declaration (2002), United Nations Johannesburg Declaration on Sustainable Development, 4 September 2002, A/CONF.199/20.

Kenny M. (1994), Ecologism, in: Political ideologies. An introduction, ed. Eccleshall R. et al., Routledge, London, pp. 218-251.

Ki-Moon B. (2015), Remarks of the United Nations Secretary-General Ban Ki-Moon at Ministerial Meeting of the Least Developed Countries on 1 October 2015, New York, http://www.un.org/sg/statements/index.asp?nid=9084 [25.06.2017]. 
Malthus T. (1798), First essay on population. (An essay on the principle of population as it affects the future improvement of society, with remarks on the speculations of Mr Godwin, M. Condorcet, and other writers), http://www.econlib.org/library/Malthus/malPop1.html [25.06.2017].

Marsh G. (1965 [1864]), Man and nature, University of Washington Press, Washington.

Mebratu D. (1998), Sustainability and sustainable development. Historical and conceptual review, „Environmental Impact Assessment Review”, vol. 18 no. 6, pp. 493-512.

Mill J.S. (1864), Principles of political economy, J.W. Parker, London.

Millennium Development Goals (2000), United Nations Millennium Declaration, Resolution Adopted by the General Assembly (55th sess. : 2000-2001), A/RES/55/2.

Moore H. (2015), Global prosperity and sustainable development goals, „Journal of International Development", vol. 27, pp. 801-815.

Paris Agreement (2015), United Nation Framework Convention on Climate Change, Adoption of Paris Agreement, FCCC/CP/2015/L.9, adopted on 12 December 2015.

Pearce D., Markandya A., Barbier E. (1989), Blue print for a green economy, Earthscan Publications, London.

Pearce F. (1992), Earth at the mercy of national interests - Fred Pearce reports from Rio de Janeiro on the final days of the Earth Summit, „New Scientist”, no. 1826, https://www.newscientist.com/article/mg13418260-300-earth-summit-earth-at-the-mercy-of-nationalinterests-fred-pearce-reports-from-rio-de-janeiro-on-the-final-days-of-the-earth-summit/ [25.06.2017].

Peet R., Hartwick E. (2009), Theories of development. Second edition: Contentions, arguments, alternatives, Guilford Press, New York.

Rio Declaration (1992), United Nations Conference on Environment and Development. Agenda 21, Rio Declaration, Forest Principles. UN Doc. A/CONF.151/26 (vol. I).

Schumacher E.F. (1973), Small is beautiful, Blond and Briggs, London.

So A. (1990), Social change and development. Modernization, dependency, and world-system theories, Sage Publications, Newbury Park, California.

Strong M. (1992), Statement by Maurice F., Secretary General United Nations Conference on Environment \& Development at Plenary Meeting Closing the United Nations Conference on Environment \& Development, Rio De Janeiro, Brazil 14 June 1992, http://www.un.org/documents/ga/conf151/aconf15126-4.htm [25.06.2017].

The Future We Want (2012), United Nations General Assembly Resolution of 27 July 2012, The Future We Want, A/RES/66/288.

Transforming our world. The 2030 Agenda for Sustainable Development (2015), United Nations Resolution adopted by the General Assembly on 25 September 2015, A/RES/70/1. 


\section{BETWEEN DEVELOPMENT AND SUSTAINABILITY ...}

Von Wright G.H. (1997), Progress. Fact and fiction, in: The idea of progress, eds. Burgen A., McLaughhlin P., Mittelstrab J., Walter de Gruyter, Berlin, pp. 1-19.

Wallace A.R. (1898), The wonderful century; its successes and its failures, George N. Morang, Toronto.

WCED (1987), Our common future, Brundtland, Oxford University Press, Oxford, http://www.undocuments.net [25.06.2017].

\section{Pomiędzy rozwojem a zrównoważonym rozwojem: symbiotyczna synergia czy dwuznaczność nie do pogodzenia}

\section{Streszczenie}

Cel: Artykuł prezentuje koncepcję zrównoważonego rozwoju, która w ostatnim czasie jest silnie obecna na globalnej scenie debat nad kwestiami najważniejszymi dla ludzkości, w rozmaitych kontekstach politycznych, prawych, społecznych i środowiskowych. Koncept został przywłaszczony przez rządy i organizacje pozarządowe. Postuluje on promowanie zarówno ciągłego wzrostu, jak i odwrócenie tendencji nieograniczonego wzrostu. Celem niniejszego artykułu jest prześledzenie historii koncepcji rozwoju i zrównoważonego rozwoju, jego ewolucji i aktualnego stanu oraz kwestionowanie, czy przyszłe zmiany w obszarze zrównoważonego rozwoju przyczynią się do wspierania „rozwoju”, poprzez dążenie do maksymalnego wzrostu gospodarczego, przepływów kapitału i inwestycji, konsumpcji i produkcji; czy ważna jest kwestia „zrównoważenia” i uwzględnienia ochrony środowiska, praw człowieka i klimatu jako priorytetu.

Układ / Metoda badawcza: Artykuł przedstawia historyczne pochodzenie i rozwój koncepcji rozwoju i zrównoważonego rozwoju, od rewolucji przemysłowej z XVIII wieku, gdzie postęp utożsamiany był ze wzrostem gospodarczym i postępem materialnym. $Z$ drugiej strony koncepcja zrównoważonego rozwoju jest ściśle związana z relacjami człowieka z naturą, która to przeszła głęboką zmianę, gdy ludzie zaczęli zakładać stałe osady, udomowiać zwierzęta i uprawiać ziemię. W tym artykule wyjaśniono, jak koncept zrównoważonego rozwoju urósł do politycznego znaczenia po publikacji raportu Brundtland w 1987 roku i jak kolejne globalne inicjatywy polityczne, takie jak Agenda 21, deklaracja z Johannesburga i Agenda 2030 poszerzyły znaczenie tego terminu i potwierdziły, że koncept zrównoważonego rozwoju stanowi ważny element międzynarodowego porządku.

Wnioski/wyniki: Artykuł podsumowuje, że główny kontekst zrównoważonego rozwoju koncentruje się na utrzymaniu wzrostu gospodarczego, który nadal pozostaje głównym celem globalnym, ze wzrostem świadomości ekologicznych zagrożeń dla planety jedynie jako tło, na którym ciągły wzrost gospodarczy wymaga podtrzymania.

Oryginalność / Wartość artykułu: Niniejsza praca ilustruje, w jaki sposób koncept zrównoważonego rozwoju urósł w skali globalnej, a tym samym stracił na znaczeniu, będąc utożsamiany niemal ze wszystkim.

Słowa kluczowe: zrównoważony rozwój, rozwój, raport Brundtland, Agenda 2030

JEL: O44, Q56 